TAO, Vol. 16, No. 4, I-VI, October 2005

\title{
Preface to the Special Issue on Geochemical Investigations on Geohazards
}

\author{
Tsanyao Frank Yang, Cheng-Hong Chen and Tsung-Kwei Liu
}

Geological hazards (Geohazards), when triggered by earthquakes and volcanic eruptions, usually cause severe damage and can result in huge casualties. Unfortunately, these natural hazards are often unexpected, seemingly unavoidable and frequently catastrophic in their impact on living environments. However, if such natural attacks can be detected in advance with a full understanding of their causes and processes, mitigations can then be taken to avert the worst effects.

The key to understanding such geohazards lies in recognizing connective patterns and linking different precursory phenomena together. In addition to geological and geophysical surveys, geochemical investigations, particularly along fault systems, can provide useful and even crucial clues toward this effort. In recent decades, many on-site and in situ geochemical measurements, and delicate laboratory analyses have become possible due to significant improvements in analytical techniques. Large amounts of geochemical data have been accumulated and integrated giving feasibility to the prospect of hazard mitigation through our better understanding of the processes involved.

After the 1999 Chi-Chi earthquake hit Taiwan causing thousands of casualties many investigations and systematic studies on geohazards, especially on earthquakes and active faults have been conducted in Taiwan. Many special issues relevant to this subject have been published, however, most are focused on geological and geophysical results and discussions (e.g., Central Geological Survey 2000; Wang et al. 2000; Teng et al. 2001; Tsai and Liu 2004) with very few discussing geochemical results. Recently a good deal of important geochemical data has been obtained and relevant conclusions made in regards to not only Taiwan (e.g., Chyi et al. 2001; Song et al. 2003; Fu et al. 2005; Walia et al. 2005a; Yang et al. 2003; 2005b, c) but also other areas/countries (e.g., Biagi et al. 2000; Heinicke and Martinelli 2005; Yang et al. 2005a). In our reckoning, it is worth compiling the current achievements of these geohazard investigations for comparison with similar geochemical approaches worldwide. Therefore, we invited colleagues who have been working in the geochemical field for many years to contribute their experience and recent works for this special issue to demonstrate the recent progress in this field.

Totally twelve representative contributions have been included in this special issue. Among them, five papers focus on earthquakes, three on eruption-related studies and four discuss other geohazards, including poisonous natural gases at a fault zone and petroliferous basin, gushing groundwater in a tunnel construction project, and pollutants spread through flooding.

In the first group of five papers, long-term monitoring results have been widely used as a basic approach to the provision of important data to aid better understanding and surveillance of earthquake activity (Italiano et al. 2005; Ramirez-Guzman et al. 2005; Song et al. 2005; Chyi et al. 2005; Walia et al. 2005b). From case studies in Italy, Italiano et al. (2005) demonstrate that cold waters, which are normally exploited for drinking purposes, can also suffer 
from geochemical modifications induced by seismicity. Ramirez-Guzman et al. (2005) report geochemical variations of hot springs in Mexico and suggest that they are sensitive to seismic activity and suitable for further monitoring. After more than a year of monitoring in Taiwan, Song et al. (2005) suggest that those sites with hot springs from deeper reservoirs and artesian springs from a smaller subsurface water body would be more sensitive and suitable for the purposes of earthquake precursory monitoring. Chyi et al. (2005) and Walia et al. (2005b) deployed soil radon measurement to monitor earthquakes. Chyi et al. (2005) find that time series register spike-like anomalies can be precursors of earthquakes. Meanwhile, Walia et al. (2005b) also note that radon anomaly is not only influenced by seismic parameters but also by meteorological parameters and the nature of carrier gases and fluids. To better understand the phenomenon, Walia et al. (2005b) suggest simultaneous recording of various gases (e.g., He, $\mathrm{CO}_{2}$, and $\mathrm{CH}_{4}$ ) and meteorological parameters, together with multiple continuous measurements of radon are necessary. At the very least, it is worth noting that automatic continuous monitoring technique has become more important in recording the short period of anomalies/ precursors (Chyi et al. 2005).

In the second group of three papers, systematic geochemical studies of fumarolic gases at Mt. Etna, Italy (Pecoraino and Giammanco 2005), the Tatun Volcano Group (TVG) of northern Taiwan (Lee et al. 2005), and lavas of the Bicol arc in the Philippines (Andal et al. 2005) are reported to better constrain their magma sources, understand volcanic activity, and estimate potential geohazards in these areas. Pecoraino and Giammanco (2005) explain some anomalous changes to gas compositions in terms of progressive gas releases from separate batches of magma that ascend towards the surface in a step-wise manner. They suggest that magma keeps accumulating beneath the volcano, thus increasing the probability of a new large eruption at Mt. Etna. Lee et al. (2005) conduct the first systematic analysis of fumarolic gas compositions at the TVG, where hydrothermal activity is quite prevalent and the area considered volcanically active. By comparison with other volcanic gases worldwide, the TVG gases show typical low temperature volcanic gas composition with high methane concentrations and $\mathrm{H}_{2} \mathrm{~S} / \mathrm{SO}_{2}$ ratios. Furthermore, most TVG gases fall in the range of hydrothermal gases and exhibit affinity with convergent plate gases. This suggests degassing sources for the TVG gases are closely related to the subduction process in NE Taiwan. Based on petrographic and geochemical data, Andal et al. (2005) determine volcanic-product types and their associated hazards in the Bicol arc. They conclude that the hazards generally associated with eruptions at the three active volcanoes in the Bicol Arc are lava flows, pyroclastic flows, airfall tephra, debris avalanches and lahars. These geohazards, specifically debris avalanches and lahars, have been the cause of huge disasters in the surrounding communities.

In the third group of four papers, Etiope et al. (2005a, b) report high carbon dioxide and radon concentrations at a fault zone (Italy); and high methane and hydrogen sulfide seepage in a petroliferous basin (Greece), respectively. In the first case, huge emissions of carbon dioxide and radon are potentially fatality to humans and fauna. In the latter case, methane is seeping in potentially explosive amounts and, hydrogen sulfide gas concentrations are high enough to induce toxicological diseases and be lethal to people. In addition, such gas-charged sediments in the seafloor and their bubbling plumes present a high risk to offshore construction. Liu et al. (2005), investigating gushing water during the Hsuehshan Tunnel construction in northern 
Taiwan, measure carbon and tritium isotopic compositions and recognize two different recharge sources for the gushing groundwater. Such isotopic compositions reflect local hydrogeological characteristics of the rock formations along the tunnel and are helpful in assessing excavation methods. Knittel et al. (2005) recognize that flood sediments contaminated by material derived from waste dumps and tailings constitute a considerable risk for land use. They further conclude that flood events may spread contaminants over large areas, where tailings and waste dumps are not sufficiently protected from erosion.

Over all, this special issue collects representative updated results of geochemical investigations of a variety of geohazards worldwide. In addition to the important basic data in different areas, readers will learn the most recent analytical techniques and approaches being applied in these works. We expect it will become an important reference for not only geochemists but also those who are working and/or concerned with the topic of geohazards.

We are grateful to all the authors and to the reviewers (listed below), who made this special issue possible: B. S. Bajwa (Guru Nanak Dev Univ.), P. F. Biagi (Univ. Bari), A. Caprai (National Research Council, Italy), P. Castillo (Scripps Institution Oceanography), C. H. Chen (Academia Sinica), Y. Chia (National Taiwan Univ.), V.M. Choubey (Wadia Institute Himalayan Geology), S. Feige (SARAD Environmental Instruments), T. Fischer (Univ. New Mexico), J. Heinicke (Saxon Academy of Sciences), S. C. Hsu (Academia Sinica), I. S. Kim (Radon Research Group), C. W. Liu (National Taiwan Univ.), K. K. Liu (National Central Univ.), T. Ohba (Tokyo Institute Technology), N.M. Perez (Poligono Industrial de Granadilla), N. Segovia (ININ), Y. N. Shieh (Purdue Univ.), S. Singh (Guru Nanak Dev Univ.), P. Sulovsky (Masaryk Univ.), D. Tedesco (Dipartimento Scienze Ambientali, SUN), W. Tumpling (Dept. Inland Water Research, Magdeburg), O. Vaselli (Univ. Florence), C. H. Wang (Academia Sinica), B. Zmazek (J. Stefan Institute).

Finally, we dedicate this special issue to the Central Geological Survey (CGS) and National Science Council of Taiwan, Republic of China for their continuous support and promotion of the geochemical investigations in Taiwan and making the present progress possible. CGS financially supported the publication of this special issue.

\section{REFERENCES}

Andal, E. S., G. P. Yumul, Jr., E. L. Listanco, R. A. Tamayo, Jr., C. B. Dimalanta, and T. Ishii, 2005: Characterization of the Pleistocene volcanic chain of the Bicol Arc, Philippines: implications for geohazard assessment. Terr. Atmos. Ocean. Sci., 16, 865-883.

Biagi, P. F., S. P. Kingsley, and F. Vallianatos, 2000: Earthquake precursors. Phy. Chem. Earth, Part A-Solid Earth and Geodesy, 25, 225-225.

Central Geological Survey, 2000: Special issue for the Chi-Chi Earthquake, 1999. Spec. Publ. Cen. Geol. Surv., 12, 271 pp.

Chyi, L. L., C. Y. Chou, T. F. Yang, and C. H. Chen, 2001: Continuous radon measurements in faults and earthquake precursor pattern recognition. Western Pac. Earth Sci., 1, 227246. 
Chyi, L. L., T. J. Quick, T. F. Yang, and C. H. Chen, 2005: Soil gas radon spectra and earthquakes. Terr. Atmos. Ocean. Sci., 16, 763-774.

Etiope, G., M. Guerra, and A. Raschi, 2005a: Carbon dioxide and radon geohazards over a gas-bearing fault in the Siena Graben (Central Italy). Terr. Atmos. Ocean. Sci., 16, 885-896.

Etiope, G., G. Papatheodorou, D. Christodoulou, P. Favali, and G. Ferentinos, 2005b: Gas hazard induced by methane and hydrogen sulfide seepage in the NW Peloponnesus petroliferous basin (Greece). Terr. Atmos. Ocean. Sci., 16, 897-908.

Fu, C. C., T. F. Yang, V. Walia, and C. H. Chen, 2005: Reconnaissance of soil gas composition over the buried fault and fracture zone in southern Taiwan. Geochem. J., 39, 427-439.

Heinicke, J., and G. Martinelli, 2005: Preface: an historical overview of gas geochemistry. An. Geophys., 48, V-VIII.

Italiano, F., A. Caracausi, R. Favara, P. Innocenzi, and G. Martinelli, 2005: Geochemical monitoring of cold waters during seismicity: implications for earthquake-induced modification in shallow aquifers. Terr. Atmos. Ocean. Sci., 16, 709-729.

Knittel, U., W. Klemm, and A. Greif, 2005: Heavy metal pollution downstream of old mining camps as a result of flood events: an example from the Mulde River System, eastern part of Germany. Terr. Atmos. Ocean. Sci., 16, 919-931.

Lee, H. F., T. F. Yang, T. F. Lan, S. R. Song, and S. Tsao, 2005: Fumarolic gas composition of the Tatun Volcano Group, northern Taiwan. Terr. Atmos. Ocean. Sci., 16, 843-864.

Liu, T. K., C. H. Chen, T. F. Yang, and M. Lee, 2005: Tritium concentrations and radiocarbon ages of gushing groundwater from Hsueshan Tunnel, Northern Taiwan. Terr. Atmos. Ocean. Sci., 16, 909-917.

Pecoraino, G., and S. Giammanco, 2005: Geochemical characterization and temporal changes in parietal gas emissions at Mt. Etna (Italy) during the period July 2000-July 2003. Terr. Atmos. Ocean. Sci., 16, 805-841.

Ramirez-Guzman, A., Y. A. Taran, R. Bernard, E. Cienfuegos, and P. Morales, 2005: Variations in the $\mathrm{Cl}, \mathrm{SO}_{4}, \delta \mathrm{D}$ and $\delta{ }^{18} \mathrm{O}$ in water from thermal springs near Acapulco, Guerrero, Mexico, related to seismic activity. Terr. Atmos. Ocean. Sci., 16, 731-743.

Song, S. R., Y. L. Chen, C. M. Liu, W. Y. Ku, H. F. Chen, Y. J. Liu, L. W. Kuo, T. F. Yang, C. H. Chen, T. K. Liu, and M. Lee, 2005: Hydrochemical changes of spring waters in Taiwan: implications for evaluating sites for earthquake precursory monitoring. Terr. Atmos. Ocean. Sci., 16, 745-762.

Song, S. R., W. Y. Ku, Y. L. Chen, Y. C. Lin, C. M. Liu, L. W. Kuo, T. F. Yang, and H. J. Lo, 2003: Groundwater chemical anomaly before and after the Chi-Chi earthquake in Taiwan. Terr. Atmos. Ocean. Sci., 14, 311-320.

Teng, T. L., Y. B. Tsai, and W. H. K. Lee, 2001: Preface to the 1999 Chi-Chi Earthquake Special issue. Bull. Seis. Soc. Am., 91, 893-894.

Tsai, Y. B., and J. Y. Liu, 2004: Preface to the special issue on Earthquake Precursors.Terr. Atmos. Ocean. Sci., 15, I-IV.

Walia, V., T. C. Su, C. C. Fu, and T. F. Yang, 2005a: Spatial variations of radon and helium concentration in soil gas across Shan-Chaio fault, Northern Taiwan. Radiat. Meas., 40, 513-516. 
Walia, V., H. S. Virk, T. F. Yang, S. Mahajan, M. Walia, and B. S. Bajwa, 2005b: Earthquake prediction studies using radon as a precursor in N-W Himalayas, India: a case study. Terr. Atmos. Ocean. Sci., 16, 775-804.

Wang, C., S. K. Hsu, H. Kao, and C. Y. Wang, 2000: Special issue on the 1999 Chi-Chi Earthquake in Taiwan-preface. Terr. Atmos. Oceanic Sci., 11, i-ii.

Yang, T. F., C. Y. Chou, C. H. Chen, L. L. Chyi, and J. H. Jiang, 2003: Exhalation of radon and it carrier gases in SW Taiwan. Radiat. Meas., 36, 425-429.

Yang, T. F., F. Italiano, and J. Heinicke, 2005a: Special issue on Recent Progress in Gas Geochemistry - preface. Geochem. J., 39, 395.

Yang, T. F., T. F. Lan, H. F. Lee, C. C. Fu, P. C. Chung, C. H. Lo, C. H. Chen, C. T. A. Chen, and C. S. Lee, 2005b: Gas compositions and helium isotopic retios of fluid samples around Kueishantao, NE offshore Taiwan and its tectonic implications. Geochem. J., 39, 469-480.

Yang, T. F., V. Walia, L. L. Chyi, C. C. Fu, C. H. Chen, T. K. Liu, S. R. Song, C. Y. Lee, and M. Lee, 2005c: Variations of soil radon and thoron concentrations in a fault zone and prospective earthquakes in SW Taiwan. Radiat. Meas., 40, 496-502. 


\section{Responsible Editor:}

Ching-Ying Lan

Institute of Earth Sciences, Academia Sinica

E-mail:kyanite@earth.sinica.edu.tw

\section{Guest Editors:}

Cheng-Hong Chen

National Applied Research Laboratories and

Department of Geosciences, National Taiwan University

E-mail: chench@ntu.edu.tw

Tsung-Kwei Liu

Department of Geosciences, National Taiwan University

E-mail: liutk@ntu.edu.tw

\section{Executive Guest Editor:}

Tsanyao Frank Yang

Department of Geosciences, National Taiwan University

E-mail: tyyang@ntu.edu.tw 